Journal of Health, Education and Literacy (J-Healt)

https://ojs.unsulbar.ac.id/index.php/j-healt/

\title{
Faktor-Faktor Yang Berhubungan Dengan Status Gizi Anak Balita Di Posyandu Model Pucuk Desa Pokkang Wilayah Kerja Puskesmas Beru- Beru Mamuju
}

\author{
Yuliana $\mathrm{D}^{1,}$ Abdul Jalil Hasan ${ }^{2}$
}

Stikes St. Fatimah Mamuju

\begin{tabular}{l}
\hline Keywords : \\
Immunization, $\quad$ Eating
\end{tabular}

Kontak :

Yuliana D

Email : yuliana12@gmail.com

STIKES ST. FATIMAH MAMUJU

DOI : https://doi.org/10.31605/j-

healt.v1i1

\section{(C)2018 J-Healt}

ini adalah artikel dengan akses terbuka dibawah licenci CC BY-NC-4.0

https://creativecommons.org/licenses/by-nc/4.0/

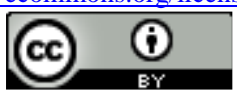

\begin{abstract}
Abstrak
Imunisasi merupakan suatu cara untuk meningkatkan kekebalan terhadap suatu antigen yang dapat dibagi menjadi imunisasi aktif dan imunisasi pasif. Sistem kekebalan tersebut yang menyebabkan balita menjadi tidak terjangkit sakit. Apabila balita tidak melakukan imunisasi, maka kekebalan tubuh balita akan berkurang dan akan rentan terkena penyakit. Hal ini mempunyai dampak yang tidak langsung dengan kejadian gizi. Penelitian ini dilakukan di Posyandu Model Pucuk Desa Pokkang wilayah kerja Puskesmas Beru-Beru Mamuju. Tujuan penelitian ini untuk mengetahui faktor- faktor apa saja yang berhubungan dengan status gizi anak balita di posyandu model pucuk dengan menggunakan metode deskriptif analitik dengan pendekatan cross sectional study dengan teknik pengambilan sampel Accidental Sampling dengan jumlah sampel 47 ibu dan anak balita yang sesuai dengan kriteria inklusi. Hasil penelitian menunjukan bahwa : Tidak ada hubungan yang signifikan antara kelengkapan imunisasi dengan status gizi anak balita dengan nilai $p$ value $=1,000>\alpha 0,05$. Ada hubungan yang signifikan antara pola makan anak balita dengan status gizi anak balita dengan nilai $\mathrm{p}$ value $=0,000>\alpha 0,05$. Ada hubungan yang signifikan antara pendidikan ibu dengan status gizi anak balita dengan nilai $\mathrm{p}$ value $=0,024>\alpha 0,005$ dan ada hubungan yang signifikan antara pengetahuan ibu dengan status gizi anak balita dengan nilai $\mathrm{p}$ value $=$ $0,000<\alpha 0,05$.
\end{abstract}

\section{Abstract}

Immunization is a way of boosting immunity to an antigen that can be divided into active immunization and passive immunization. The immune system that causes toddlers to be not sick. If toddlers do not immunize, then the immune system will be reduced and will be susceptible to disease. This has an indirect impact with the incidence of nutrition. This research was conducted at Posyandu Model Pucuk Desa Pokkang working area Beru-Beru District Health Center. The objective of this research is to know what factors are related to nutritional status of children under five in posyandu model shoot by using analytical descriptive method with cross sectional study approach with sampling technique of Accidental Sampling with sample number of 47 mothers and children under five with inclusion criteria. The results showed that: There is no significant relationship between the completeness of immunization with nutritional status of children under five with $p$ value $=1,000>\alpha$ 0.05. There is a significant correlation between toddler's diet with nutritional status of children under five with $p$ value $=0,000>$ $\alpha$ 0,05. There is a significant correlation between maternal education with nutritional status of children under five with $p$ value $=0,024>\alpha$ 0,005 and there is a significant correlation between mother knowledge with nutritional status of children under five with $p$ value $=0,000<\alpha$ 0.05 . 


\section{PENDAHULUAN}

Kesehatan merupakan hak asasi manusia dan modal investasi bangsa yang dapat mempengaruhi kualitas sumber daya manusia di suatu negara. Semakin baik tingkat kesehatan penduduk maka akan berhubungan positif dengan kualitas penduduk tersebut. Individu yang sehat akan memiliki kemampuan untuk melakukan aktivitas produksi yang baik dan optimal. Tingkat kesehatan seseorang dapat dilihat dari status gizi orang tersebut. Selain itu Kualitas Sumber Daya Manusia (SDM) merupakan faktor utama yang diperlukan untuk melaksanakan pembangunan nasional. Untuk mencapai SDM yang berkualitas faktor gizi memegang peranan penting. Gizi yang baik akan menghasilkan SDM yang berkualitas yaitu sehat, cerdas dan memiliki fisik yang tangguh serta produktif. Perbaikan gizi diperlukan pada seluruh siklus kehidupan, mulai dari masa kehamilan, bayi dan balita, pra sekolah, anak SD dan MI, remaja dan dewasa sampai usia lanjut (Depkes RI, 2015).

Status gizi anak balita di Indonesia saat ini masih memprihatinkan (Mustafa, dkk, 2013). Beberapa penelitian telah menyatakan bahwa status gizi anak Indonesia masih jauh dari harapan (Melayu, 2014). Masalah gizi buruk dan gizi kurang nampaknya belum bisa teratasi dengan baik dalam skala internasional maupun nasional, tercatat 101 juta anak di dunia dibawah lima tahun menderita kekurangan gizi, Balita yang termasuk gizi kurang mempunyai resiko meninggal lebih tinggi dibandingkan balita yang gizinya baik (UNICEF, 2013).

Ada beberapa faktor yang mempengaruhi status gizi pada balita diantaranya adalah pengetahaun. Menurut Abu (2010) Pengetahuan yang dimiliki ibu berpengaruh terhadap pola konsumsi makanan keluarga. Kurangnya pengetahuan ibu tentang gizi menyebabkan keanekaragaman makanan yang berkurang. Keluarga akan lebih banyak membeli barang karena pengaruh kebiasaan, iklan, dan lingkungan. Selain itu, gangguan gizi juga disebabkan karena kurangnya kemampuan ibu menerapkan informasi tentang gizi dalam kehidupan sehari-hari. Status gizi pada masyarakat dipengaruhi oleh banyak faktor. Kondisi sosial ekonomi merupakan salah satu faktor penting yang mempengaruhi status gizi. Bila kondisi sosial ekonomi baik maka status gizi diharapkan semakin baik. Status gizi anak balita akan berkaitan erat dengan kondisi sosial ekonomi keluarga (orang tua), antara lain pendidikan orang tua, pekerjaan orang tua, jumlah anak orang tua, pengetahuan dan pola asuh ibu serta kondisi ekonomi orang tua secara keseluruhan (Supariasa, 2002).

Data yan dicatat oleh Organisasi Kesehatan Dunia (WHO) pada tahun 2004 ada 5.119.935 anak balita yang menderita gizi kurang dan buruk. Kondisi buruk, termasuk busung lapar yang belakangan ini terungkap, sebenarnya dapat dicegah. Gizi buruk sebenarnya masalah yang bukan hanya disebabkan oleh kemiskinan. Juga karena aspek sosial budaya yang ada dimasyarakat kita sehingga, sehingga menyebabkan tindakan yang tidak menunjang tercapaianya gizi yang memadai untuk balita (masalah individual dalam keluarga) (Kompas.Com. 2009).

Berdasarkan penimbangan balita di posyandu, ditemukan sebanyak 26.518 balita gizi buruk secara nasional. Kasus gizi buruk yang dimaksud ditentukan berdasarkan perhitungan berat badan menurut tinggi badan balita $\mathrm{Z}$ score < -3 standar deviasi (balita sangat kurus). Sedangkan menurut hasil Riskesdas 2013 prevalensi gizi sangat kurus pada balita sebesar 5,3\%. Jika diestimasikan terhadap jumlah sasaran balita (S) yang terdaftar di posyandu yang melapor (21.436.940) maka perkiraan jumlah balita gizi buruk (sangat kurus) sebanyak sekitar 1,1 juta jiwa (Kemenkes RI, 2015).

Berdasarkan penimbangan balita di posyandu, ditemukan sebanyak 319 balita gizi kurang di Provinsi Sulawesi Barat. Sebanyak 319 kasus gizi kurang yang ditemukan mendapatkan perawatan (100\%). Kasus gizi kurang yang 
dimaksud ditentukan berdasarkan perhitungan berat badan menurut tinggi badan balita Zscore $<-3$ standar deviasi (balita sangat kurus). Sedangkan menurut hasil Pemantaun Status Gizi Tahun 2015 prevalensi gizi sangat buruk dan kurang pada balita sebesar 24,7\%. Jika diestimasikan terhadap jumlah sasaran balita (S) yang terdaftar di posyandu yang melapor $(129,863)$ maka perkiraan jumlah balita gizi kurang dan buruk sebanyak sekitar 32.076 jiwa (Dinkes Sulbar, 2015).

Data yang diperoleh di posyandu Model Pucuk di desa pokkang jumlah anak balita umur 12 - 59 bulan yang terdaftar dari tahun 2015 sampai bulan maret 2017 sebanyak 596 anak balita. Tahun 2015 sebanyak 236 (39,5\%), tahun 2016 sebanyak 242 anak balita $(40,5 \%)$ dan tahun 2017 mulai Januari sampai bulan maret sebanyak 120 anak balita (20,0\%). Selain itu, pada tahun 2015 terdapat 236 anak balita dengan BB naik dan sebanyak 110 orang $(46,6 \%)$, BB turun sebanyak 60 orang $(25,4 \%)$, dan terdapat anak balita yang kurang aktif sebanyak 45 orang $(19,1 \%)$, BB dengan bawah garis merah sebanyak 5 orang ( $2,1 \%$ ) dan BB dengan bawah garis kuning sebanyak 16 orang (6,8\%). Pada tahun 2016 terdapat 242 anak balita dengan BB naik sebanyak 112 orang $(46,2 \%)$, BB turun sebanyak 61 orang $(25,2 \%)$, anak balita yang kurang aktif sebanyak 48 orang (19,8\%), BB dengan bawah garis merah sebanyak 5 orang $(2,1 \%)$ dan BB dengan bawah garis kuning sebanyak 16 orang $(6,7 \%)$. Pada tahun 2017 dari bulan January sampai bulan maret terdapat 120 anak balita dengan $\mathrm{BB}$ naik sebanyak 44 orang (36.6\%), BB turun 28 orang $(23,3 \%)$, anak balita yang kurang aktif sebanyak 42 orang (35\%), BB dengan bawah garis merah sebanyak 2 orang $(1,7 \%)$, BB dengan bawah garis kuning sebanyak 4 orang (3,4\%) (Puskesmas Beru-Beru, 2017).

Hasil wawancara dengan Kader mengatakan bahwa rata-rata ibu yang mempunyai anak balita yang terdaftar di Posyandu Model Pucuk desa Pokkang, pendidikan kurang 60 $\%$, pekerjaan $70 \%$ ibu rumah tangga, $20 \%$ petani, $10 \%$ honorer/PNS. (Sumber data primer Posyandu Model Pucuk, 2017).
Berdasarkan data awal tersebut maka peneliti tertarik untuk meneliti " Faktor-faktor yang berhubungan dengan status gizi anak balita di Posyandu Model Pucuk desa Pokkang kecamatan Kalukku kabupaten Mamuju tahun $2017 "$.

\section{METODE}

Dalam penelitian ini yang akan digunakan adalah metode deskriptif analitik dengan pendekatan cross sectional dimana penelitian yang dilakukan dengan meninjau variabel dependen dan variabel independen pada waktu bersamaan sehingga dapat ditarik adanya hubungan signifikansi dari dua variable tersebut. Populasi dalam penelitian ini adalah semua responden ibu yang mempunyai anak balita 1-4 tahun 11 bulan (dibawah 5 tahun) yang memenuhi kriteria inklusi. Dengan jumlah 120 anak balita yang terdaftar di Posyandu Model Pucuk desa Pokkang. Instrumen yang digunakan adalah lembar kuesioner, untuk mengukur variabel kelengkapan imunisasi dan pola makan anak balita dengan skala gutman dimana pilihan jawaban Ya dan Tidak, pengukurannya variabel pendidikan dan pekerjaan ibu menggunakan skala nominal, untuk mengukur pengetahuan ibu menggunakan kuesioner dengan pilihan jawaban yang paling benar dan untuk mengukur status gizi dengan menggunakan alat ukur antropometri.

\section{HASIL}

\section{Analisa Univariat}

Tabel 1. Distribusi karakteristik responden di Posyandu Model Pucuk Desa Pokkang Mamuju

\begin{tabular}{ccc}
\hline Karakteristik & $\mathrm{n}$ & $(\%)$ \\
\hline Umur ibu & & \\
18-25 Tahun & 15 & 31.9 \\
26-35 Tahun & 19 & 40.4 \\
>36 Tahun & 13 & 27.7 \\
\hline Pendidikan ibu & & \\
Tamat SD & 20 & 42.6 \\
Tamat SMP & 12 & 25.5 \\
Tamat SMA/SMK & 11 & 23.4 \\
Strata 1 & 4 & 8.5 \\
\hline
\end{tabular}




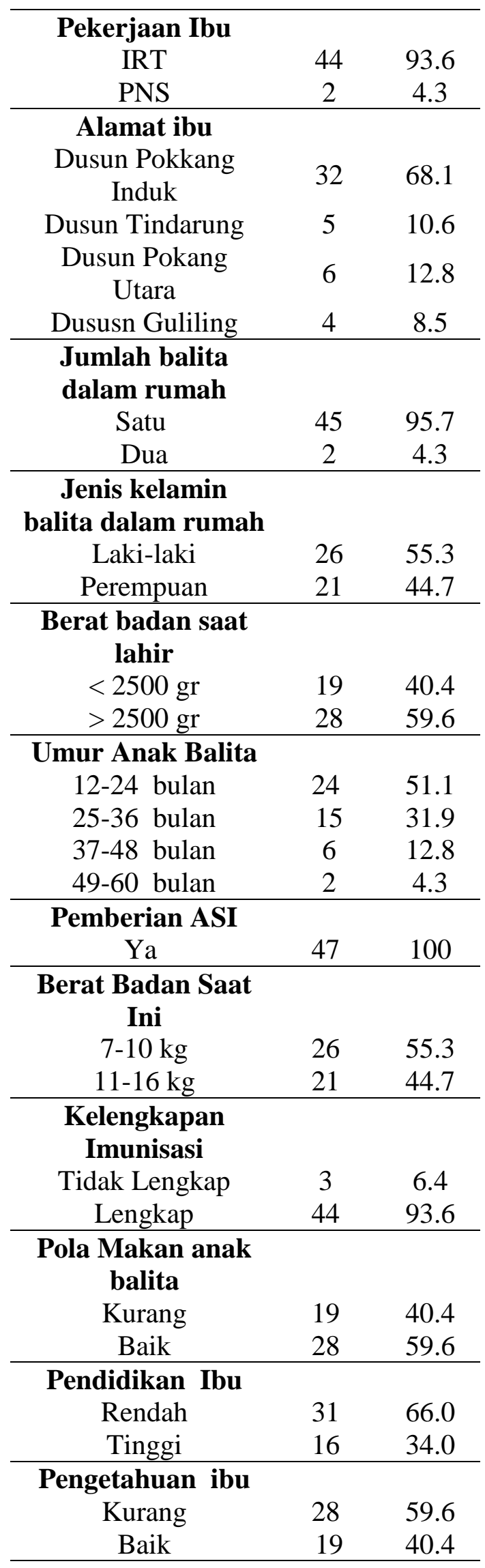

\begin{tabular}{ccc}
\hline $\begin{array}{c}\text { Status gizi anak } \\
\text { balita }\end{array}$ & & \\
Tidak Normal & 17 & 36.2 \\
Normal & 30 & 63.8 \\
\hline Jumlah & 47 & 100 \\
\hline
\end{tabular}

Jumlah umur ibu tertinggi kategori 26-35 Tahun sebanyak 19 orang $(40,4 \%)$, dan terendah kategori umur ibu $>36$ Tahun sebanyak 13 orang $(27,7 \%)$. pendidikan ibu tertinggi kategori SD sebanyak 20 orang $(42,6 \%)$, dan terendah pendidikan ibu sarjana sebanyak 4 orang $(8,5 \%)$. terdapat nilai tertinggi pekerjaan ibu IRT sebanyak 44 orang $(93,6 \%)$, dan terendah pekerjaan PNS sebanyak 2 orang $(4,3 \%)$. terdapat nilai tertinggi alamat ibu Dusun Pokkang Induk sebanyak 32 orang $(68,1 \%)$, dan nilai terendah alamat ibu Dusun Guliling sebanyak 4 orang $(8,5 \%)$. terdapat tertinggi jumlah balita dalam rumah yakni satu balita sebanyak 45orang $(95,7 \%)$, dan terendah jumlah balita dua orang dalam rumah sebanyak 2 orang $(4,3 \%)$. terdapat tertinggi jenis kelamin laki-laki sebanyak 26 orang $(55,3 \%)$, dan terendah jenis kelamin perempuan sebanyak 21 orang $(44,7 \%)$. terdapat berat badan saat lahir anak balita tertinggi kategori >2500 gr sebanyak 28 orang $(59,6 \%)$, dan berat badan saat lahir anak balita terendah kategori < 2500 gr sebanyak 19 orang $(40,4 \%)$. terdapat tertinggi umur anak balita 12-24 bulan sebanyak 24 orang $(51,1 \%)$, dan terendah umur anak balita 49-60 bulan sebanyak 2 orang (4.3\%). sebanyak 47 anak $(100.0 \%)$ di berikan ASI Eksklusif. Jumlah tertinggi berat badan anak balita saat ini kategori $7-10 \mathrm{~kg}$ sebanyak 26 orang $(55,3 \%)$, dan terendah berat badan anak balita saat ini kategori $>11$ $16 \mathrm{~kg}$ sebanyak 21 orang $(44,7 \%)$. Jumlah tertinggi dengan status imunisasi lengkap sebanyak 44 orang $(93,6 \%)$, dan terendah status imunisasi tidak lengkap sebanyak 3 orang $(6,4 \%)$. Junlah tertinggi pola makan anak balita baik sebanyak 28 orang $(59,6 \%)$, dan terendah pola makan anak balita kurang sebanyak 19 orang 40,4\%). Jumlah tertinggi pendidikan ibu dengan kategori rendah sebanyak 31 orang $(66,0 \%)$, dan terendah pendidikan ibu dengan kategori tinggi 
sebanyak 16 orang (34.0\%). tertinggi pengetahuan ibu dengan kategori kurang sebanyak 28 orang $(59,6 \%)$, dan terendah pengetahuan ibu dengan kategori baik sebanyak 19 orang $(40,4 \%)$. terdapat tertinggi status gizi anak balita normal sebanyak 30 orang $(63,8 \%)$, dan terendah dengan status gizi tidak normal sebanyak 17 orang $(36,2 \%)$.

\section{Analisis Bivariat}

Tabel 2. Hubungan Antara Variabel Dengan Status Gizi Anak Balita di Posyandu Model Pucuk Desa Pokkang Mamuju.

\begin{tabular}{|c|c|c|c|c|c|c|c|}
\hline \multirow{3}{*}{ Variabel } & \multicolumn{6}{|c|}{ Status Gizi Anak Balita } & \multirow{3}{*}{$\begin{array}{l}X^{2} \\
(p)\end{array}$} \\
\hline & \multicolumn{2}{|c|}{ Tdk Normal } & \multicolumn{2}{|c|}{ Normal } & \multirow{2}{*}{\multicolumn{2}{|c|}{$\begin{array}{r}\text { Jumlah } \\
\%\end{array}$}} & \\
\hline & $\mathrm{f}$ & $\%$ & $\mathrm{f}$ & $\%$ & & & \\
\hline \multicolumn{8}{|l|}{$\begin{array}{c}\text { Kelengkapan } \\
\text { imunisasi }\end{array}$} \\
\hline Tidak Lengkap & 1 & 33,3 & 2 & 66,7 & 3 & 100,0 & 0,011 \\
\hline Lengkap & 16 & 36,4 & 28 & 63,6 & 44 & 100,0 & $(1,000)$ \\
\hline \multicolumn{8}{|l|}{$\begin{array}{l}\text { Pola makan } \\
\text { anak balita }\end{array}$} \\
\hline Kurang & 15 & 78,9 & 4 & 21,1 & 19 & 100,0 & 25.278 \\
\hline Baik & 2 & 7,1 & 26 & 92,9 & 28 & 100,0 & 0.000 \\
\hline \multicolumn{8}{|l|}{ Pendidikan ibu } \\
\hline Rendah & 15 & 48,4 & 16 & 51,6 & 31 & 100,0 & 5.887 \\
\hline Tinggi & 2 & 12,5 & 14 & 87,5 & 16 & 100,0 & 0,024 \\
\hline \multicolumn{8}{|l|}{ Pengetahuan ibu } \\
\hline Kurang & 17 & 60,7 & 11 & 39,3 & 28 & 100,0 & 18.073 \\
\hline Baik & 0 & 0,0 & 19 & 100,0 & 19 & 100,0 & 0,000 \\
\hline
\end{tabular}

Berdasarkan tabel 2 diatas diperoleh hasil analisis bivariat untuk variabel kelengkapan imunisasi bahwa dari 3 anak balita yang mempunyai status imunisasi tidak lengkap sebanyak status gizi tidak normal 1 orang $(33,3 \%)$ dan status gizi normal sebanyak 2 orang $(66,7 \%)$. dari 44 anak balita yang mempunyai kelengkapan imunisasi terdapat status gizi normal sebanyak 28 orang $(63,6 \%)$ dengan status gizi tidak normal dan 16 orang $(36,4 \%)$. Hasil analisis statistik dengan uji Chi-Square diperoleh nilai $\mathrm{x} 2$ hitung $(0,011)<x 2$ tabel $(3,811)$ dan nilai $\mathrm{p}$ value $=1,000>\alpha 0,05$, hal ini berarti Hipotesa Ho diterima $\mathrm{Ha}$ di tolak artinya tidak ada hubungan yang signifikan antara kelengkapan imunisasi dengan status gizi anak balita di Posyandu Model Pucuk desa Pokkang wilayah kerja Puskesmas Beru-beru kecamatan Kalukku kabupaten Mamuju.
Hasil analisis bivariat untuk variabel pola makan anak balita diperoleh bahwa dari 19 anak balita dengan pola makan kurang , sebanyak 15 orang $(61,5 \%)$ status gizi tidak normal dan 4 orang $(21,1 \%)$ status gizi normal dan dari 28 anak balita dengan pola makan baik, sebanyak 26 orang (92,9\%) status gizi normal dan 2 orang $(7,1 \%)$ dengan status gizi tidak normal. Hasil analisis statistik dengan uji Chi-Square diperoleh nilai x2 hitung $(25,278)>x 2$ tabel $(3,811)$ dan $\mathrm{p}$ value $=0,000>\alpha 0,05$, hal ini berarti hipotesa Ha diterima Ho ditolak artinya ada hubungan yang signifikan antara pola makan anak balita dengan status gizi anak balita di Posyandu Model Pucuk desa Pokkang wilayah kerja Puskesmas Beru-beru kecamatan Kalukku kabupaten Mamuju.

Hasil analisis bivariat untuk variabel pendidikan ibu, diperoleh hasil bahwa dari 31 ibu yang mempunyai pendidikan rendah 
sebanyak 15 orang $(48,4 \%)$ dengan status gizi anak balita tidak normal dan 16 orang $(51,6 \%)$ dengan status gizi anak balita normal dan dari 16 ibu yang mempunyai pendidikan tinggi sebanyak 14 orang $(87,5 \%)$ dengan status gizi anak balita normal dan 2 orang $(12,5 \%)$ dengan status gizi anak balita tidak normal. Hasil analisis statistik dengan uji Chi-Square diperoleh nilai x2 hitung ( $5.887)>\mathrm{x} 2$ tabel $(3,811)$ dan nilai $\mathrm{p}$ value $=0,024>\alpha 0,05$, hal ini berarti hipotesa $\mathrm{Ha}$ diterima dan Ho ditolak artinya tada hubungan yang signifikan antara pendidikan ibu dengan status gizi anak balita di Posyandu Model Pucuk desa Pokkang wilayah kerja Puskesmas Beru-beru kecamatan Kalukku kabupaten Mamuju.

Hasil analisis bivariat untuk variabel pengetahuan ibu diperoleh hasil bahwa dari 28 ibu yang mempunyai pengetahuan kurang, sebanyak 17 orang $(60,7 \%)$ dengan status gizi anak balita tidak normal dan sebanyak 11 orang $(39,3 \%)$ dengan status gizi anak balita normal sedangkan pengetahuan ibu baik sebanyak 19 orang, status gizi anak balita baik sebanyak 19 anak (100\%) dan status gizi tidak normal $0(0,0 \%)$. Hasil analisis statistik dengan uji Chi-Square diperoleh nilai $\mathrm{x} 2$ hitung $(18,073)>\mathrm{x} 2$ tabel $(3,811)$ dan nilai $\mathrm{p}$ value $=0,000<\alpha 0,05$, hal ini berarti hipotesa Ha diterima dan Ho ditolak artinya ada hubungan yang signifikan antara pengetahuan ibu dengan status gizi anak balita di Posyandu Model Pucuk Desa Pokkang Wilayah kerja Puskesmas Beru-beru Kecamatan Kalukku kabupaten Mamuju. .

\section{PEMBAHASAN}

1. Variabel Kelengkapan imunisasi

Hasil analisis statistik dengan uji ChiSquare diperoleh nilai $\mathrm{x}^{2}$ hitung $(0,011)$ $<\mathrm{x}^{2}$ tabel $(3,811)$ dan nilai $p$ value $=$ $1,000>\alpha 0,05$, hal ini berarti hipotesa Ho diterima Ha di tolak artinya tidak ada hubungan yang signifikan antara kelengkapan imunisasi dengan status gizi anak balita di Posyandu Model Pucuk desa Pokkang wilayah kerja Puskesmas
Beru-beru kecamatan Kalukku kabupaten Mamuju.

Imunisasi merupakan suatu cara untuk meningkatkan kekebalan terhadap suatu antigen yang dapat dibagi menjadi imunisasi aktif dan imunisasi pasif. Imunisasi aktif adalah pemberian kuman atau racun kuman yang sudah dilemahkan atau dimatikan untuk merangsang tubuh memproduksi antibodi sendiri sedangkan imunisasi pasif adalah penyuntikan sejumlah antibodi sehingga kadar antibodi dalam tubuh meningkat. System kekebalan tersebut yang menyebabkan balita menjadi tidak terjangkit sakit. Apabila balita tidak melakukan imunisasi,maka kekebalan tubuh balita akan berkurang dan akan rentan terkena penyakit. Hal ini mempunyai dampak yang tidak langsung dengan masalah kejadian gizi kurang (Supartini, 2010).

Pada penetian ini ditemukannya tidak ada hubungan yang bermakna diasumsikan bahwa di posyandu model pucuk ibu telah memberikan imunsasi dengan lengkap, namun baik yg diberikan imunisasi maupun tidak sama-sama mempunyai peluang mengalami masalah nutrisi. terlihat dari hasil pengkajian, dari 44 anak balita yang mempunyai kelengkapan imunisasi terdapat status gizi normal sebanyak 28 orang $(63,6 \%)$ dengan status gizi tidak normal dan 16 orang $(36,4 \%)$. Selain itu juga sesuai dengan teori Tinu (2005). Beberapa faktor yang mempengaruhi status gizi anak adalah pengetahuan, sikap dan perilaku ibu dalam mendeteksi kelainan tumbuh kembang anak dan pemberian makanan sesuai umur anak dalam keluarga, pola asuh, jarak anak, pertumbuhan yang terganggu pada awal kehidupan, penyapihan terlalu cepat atau lambat, penyakit penyerta, sosial ekonomi, tradisi masyarakat, dan ketidaktahuan. 
2. Variabel pola makan anak balita

Hasil analisis statistik dengan uji ChiSquare diperoleh nilai $\mathrm{x}^{2}$ hitung $(25,278)$ $>\mathrm{x}^{2}$ tabel $(3,811)$ dan $p$ value $=0,000>$ $\alpha 0,05$, hal ini berarti hipotesa Ha diterima Ho ditolak artinya ada hubungan yang signifikan antara pola makan anak balita dengan status gizi anak balita di Posyandu Model Pucuk desa Pokkang wilayah kerja Puskesmas Beru-beru kecamatan Kalukku kabupaten Mamuju.

Di peroleh hasil demikian karena pola makan yang baik berarti anak mendapatkan kebutuhan nutrisi yang mengandung zat yang bergizi dengan demikian status gizi anak terkontrol dengan baik. Demikian pula sebaliknya, apabila pola makan anak kurang maka zat gizi seperti karbohidrat, protein, lemak, mineral, vitamin yang sangat diperlukan oleh tubuh tidak terpenuhi, sehingga sel atau jaringan tubuh dapat mengalami penurunan fungsi yang akan mempengaruhi pertumbuhan dan perkembangan anak. Elly Nurachmah ${ }^{4}$ (2001) dalam Apriyanti (2005), menyatakan status gizi seseorang tergantung juga dari pola makannya yaitu jenis makanan yang dikonsumsi mempunyai efek terhadap nutrisi. Pola makan anak dilihat dari jenis makanannya sangat dipengaruhi oleh pendapatan keluarga. Pendapatan keluarga yang tinggi atau cukup diharapkan dapat menunjang jenis makanan yang seharusnya disediakan oleh keluarga yakni berupa makanan yang bergizi. Namun, meskipun demikian bukan menjadi suatu dasar bahwa pendapatan yang tinggi maka status gizi keluarga akan baik tanpa adanya pengetahuan yang baik tentang pentingnya gizi.

Pola makan anak yang benar, merupakan hal yang sangat penting dan harus diperhatikan, sebab anak sangat membutuhkan nutrisi yang tepat bagi pertumbuhannya. Bila hal ini tidak terpenuhi, maka anak bisa menderita kekurangan gizi. Oleh karena itu, di lingkungan anak hidup terutama keluarga perlu pembiasaan makan anak yang memperhatikan kesehatan dan gizi (Tinuk, 2004).

\section{Variabel pendidikan ibu}

Hasil analisis statistik dengan uji ChiSquare diperoleh nilai $\mathrm{x} 2$ hitung (5.887) $>\mathrm{x} 2$ tabel $(3,811)$ dan nilai $\mathrm{p}$ value $=$ $0,024>\alpha 0,05$, hal ini berarti hipotesa Ha diterima dan Ho ditolak artinya tada hubungan yang signifikan antara pendidikan ibu dengan status gizi anak balita di Posyandu Model Pucuk desa Pokkang wilayah kerja Puskesmas Beruberu kecamatan Kalukku kabupaten Mamuju.

Distribusi responden berdasarkan tingkat pendidikan ibu menunjukkan pendidikan tinggi dengan status gizi kurang sebanyak $2(15,5 \%)$ orang anak. Hal ini menunjukan bahwa ibu yang berpendidikan tinggi tidak selamanya mempunyai status gizi anak baik, hal ini disebabkan akibat rutinitas ibu yang sangat padat, dimana kecenderungan ibu banyak menghabiskan waktunya ditempat kerja seperti ibu yang bekerja,ini ditunjukkan dengan adanya $3(6,4 \%)$ ibu yang bekerja.

Sedangkan ditemukannya $31 \quad(66.0 \%)$ orang anak balita yang pendidikannya rendah namun status gizi anak baik, ini disebabkan ibu yang berpendidikan rendah mempunyai sedikit peluang untuk bekerja diluar rumah sehingga kebanyakan waktunya hanya dihabiskan dirumah bersama anaknya dan seseorang yang tamat SD belum tentu kurang mampu menyusun makanan yang menurut persyaratan gizi dibandingkan orang yang pendidikannya lebih tinggi, karena sekalipun berpendidikan rendah kalau orang tersebut banyak mendapatkan informasi dan selalu turut serta dalam penyuluhan gizi pengetahuannya akan lebih baik. Mac Dowell mengatakan tak 
beda nyata pengetahuan gizi calon guru dengan tamatan SD keduanya hanya sedikit tahu dibanding dengan yang buta huruf (Apriyanti,2005).

\section{Variabel pengetahuan}

Hasil analisis statistik dengan uji ChiSquare diperoleh nilai $\mathrm{x}^{2}$ hitung $(18,073)$ $>\mathrm{x}^{2}$ tabel $(3,811)$ dan nilai $p$ value $=$ $0,000<\alpha 0,05$, hal ini berarti hipotesa $\mathrm{Ha}$ diterima dan Ho ditolak artinya ada hubungan yang signifikan antara pengetahuan ibu dengan status gizi anak balita di Posyandu Model Pucuk Desa Pokkang Wilayah kerja Puskesmas Beruberu Kecamatan Kalukku kabupaten Mamuju.

Penelitian ini sejalan dengan penelitian yang dilakukan oleh Muh. Ihsan, (2012). Bahwa prevalens rate gizi kurang tertinggi pada anak dengan pengetahuan ibu tentang gizi dengan kategori kurang yaitu $39,0 \%$. Sedangkan prevalens rate gizi baik tertinggi pada anak dengan pengetahuan ibu tentang gizi dengan kategori baik yaitu $80,9 \%$. Hasil analisa statistik diperoleh nilai $p=0,027$ artinya ada hubungan asosiasi yang signifikan antara pengetahuan ibu tentang gizi dengan status gizi anak balita.

Namun penelitian tersebut berbeda dengan penelitian yang dilakukan oleh Yoseph( 2007), yang menunjukan bahwa balita dengan status gizi kurang lebih banyak berasal dari kelompok ibu yang berpengetahuan tinggi dibandingkan dengan kelompok ibu yang berpengetahuan rendah. Hal ini dikarenakan ibu kurang menerapkan pengetahuan yang ia miliki mengenai kebutuhan gizi yang harus dipenuhi untuk anak balitanya. Berdasarkan penelitian yang dilakukan oleh Indra, mendapatkan salah satu sebab masalah gizi kurang yaitu kurangnya pengetahuan tentang gizi atau kurang menerapkan informasi tersebut dalam kehidupan sehari-hari.
Selain itu didukung oleh teori Khomsan, (2007) Penelitian ini di dukung oleh teori yang mengatakan bahwa tingkat pengetahuan gizi seseorang berpengaruh terhadap sikap dan prilaku dalam memilih makanan, yang pada akhirnya berpengaruh terhadap keadaan gizi seseorang. Tingginya tingkat pengetahuan seseorang maka diharapkan akan lebih baik juga keadaan gizinya.

Menurut teori ibu merupakan orang yang berperang penting dalam penentuan konsumsi makanan dalam keluarga khususnya pada anak balita. Pengetahuan yang dimiliki ibu berpengaruh terhadap pola konsumsi makanan keluarga. Kurangnya pengetahuan ibu tentang gizi menyebabkan keanekaragaman makanan yang berkurang. Keluarga akan lebih banyak membeli barang karena pengaruh kebiasaan, iklan, dan lingkungan. Selain itu, gangguan gizi juga disebabkan karena kurangnya kemampuan ibu menerapkan inforasi tentang gizi dalam kehidupan sehari-hari (Abu, 2010).

\section{KESIMPULAN}

1. Tidak ada hubungan yang signifikan antara kelengkapan imunisasi dengan status gizi anak balita di Posyandu Model Pucuk desa Pokkang wilayah kerja Puskesmas Beruberu kecamatan Kalukku kabupaten Mamuju tahun 2017, dengan nilai $p$ value $=1,000>\alpha 0,05$.

2. Ada hubungan yang signifikan antara pola makan anak balita dengan status gizi anak balita di Posyandu Model Pucuk desa Pokkang wilayah kerja Puskesmas Beruberu kecamatan Kalukku kabupaten Mamuju tahun 2017, dengan nilai p value $=0,000>\alpha 0,05$

3. Ada hubungan yang signifikan antara pendidikan ibu dengan status gizi anak balita di Posyandu Model Pucuk desa Pokkang wilayah kerja Puskesmas Beruberu kecamatan Kalukku kabupaten Mamuju tahun 2017, dengan nilai $\mathrm{p}$ value $=0,024>\alpha 0,05$ 
4. Ada hubungan yang signifikan antara pengetahuan ibu dengan status gizi anak balita di Posyandu Model Pucuk desa Pokkang wilayah kerja Puskesmas Beruberu kecamatan Kalukku kabupaten Mamuju tahun 2017, dengan nilai p value $=0,000<\alpha 0,05$

\section{SARAN}

a. Dianjurkan kepada puskesmas untuk memaksimalkan pengukuran tinggi badan balita di Posyandu secara rutin setiap bulan dan meningkatkan konseling tentang asupan gizi yang baik bagi balita di Posyandu

b. Dianjurkan kepada peneliti selanjutnya untuk meneliti lebih lanjut tentang masalah status gizi pada anak balita

c. Dianjurkan pada masyarakat untuk meningkatkan asupan gizi dengan cara pemberian makan bervariasi dan teratur kepada anak balita, meningkatkan konsumsi buak pada anak balita dengan cara mulai menanam bermacam-macam buah di lahan sekitar rumah dan meningkatkan pola makan gizi seimbang dan keanekaragaman pangan untuk balita terutama sayur dan buah

\section{DAFTAR PUSTAKA}

Abu A. 2010. Ilmu social dasar. Jakarta: Rineka Cipta

Adriani, M., dan Wirjatmadi, B. 2014 Peranan gizi dalam siklus kehidupan, Jakarta: Kencana

Almatsier, Sunita, Prinsip Dasar Ilmu Gizi (edisi revsi). Gramedi Pustaka utama. Jakarta. 2009

Apriyanti. (2005). Faktor-faktor yang Berhubungan dengan Status Gizi Anak pada Usia Infant. Skripsi (tidak diterbitkan). Fakultas Kedokteran Universitas Hasanuddin. Makassar.

Ari Istiany dan Rusilanti. 2013. Gizi Terapan. Bandung: PT. Remaja Rosdakarya Offset

Departemen Gizi dan Kesehatan Masyarakat. 2013. Gizi dan Kesehatan Masyarakat. Jakarta: Rajawali Pers.

Departemen Kesehatan RI. 2012. Pemantauan Pertumbuhan Balita. Jakarta:
Direktorat Gizi Departemen Kesehatan RI.

Depkes, 2007. Buletin Penelitian Sistem Kesehatan. Surabaya: Bakti Husada.

Dr. Ahmad Jauhari, M.Sc dan Nita Nasution, S.Kep. Ns. 2015. Nutrisi \& Keperawatan. Dua Satria Offset. Yogyakarta

Dr.Rita Juniriana Primisasiki, Sp.A. 2013. Mengenal Penyakit-Penyakit Balita dan Anak. PT Sunda Kelapa Pustaka

Enny Dwiastuty. 2014. Variasi Resep Praktis MPASI Harian untuk Tahun Pertama Periode Emas. Jakarta: Agromedia Pustaka

Erna Kusuma Wati, SKM, M.Si, dan Atikah Proverawati, SKM, MPH. Ilmu Gizi untuk Keperawatan \& Gizi Kesehatan. Nusa Medika. Yogyakarta. 2011

Handayani IS. Hubungan Antara Sosial Ekonomi Keluarga dengan Status Gizi Balita Indonesia [serial online]. 2008 (diunduh 24 Agustus 2013). Tersedia dari:URL:HYPERLINKhttp://repositor y.ipb.ac.id/bitstream/handle/123456789 /50164/G08ish2.

Hasbullah. 2005. Dasar-Dasar Ilmu Pendidikan. Ed 1. Raja Grafinda Opersada. Jakarta.

Hidayat, A. Aziz Alimul. 2007. Metode Penelitian dan Teknik Analisis Data. Salemba Medika : Jakarta.

Hidayat AAA.2008. Pengantar Ilmu Kesehatan Anak untuk Pendidikan Kebidanan. Jakarta:Salemba Medika

Hurlock. Elizabeth (2007), Psikologi Perkembangan Anak. Erlangga. Jakarta Intanghina, 2008. Peran Serta Ibu Balita Dalam Kegiatan Penimbangan. http://intanghina.wordpress.com

Iskandar, 2009. Hubungan Tingkat Pengetahuan Masyarakat Tentang Peran Dan Fungsi Posyandu Terhadap Motivasi Kunjungan Di Posyandu Desa Mendala Kecamatan Sirampong Kabupaten Brebes. Sripsi

Kementrian Kesehatan republic Indonesia, 2011, Kemenkes RI no. 1995/MENKES/SK/XII/2010. Standar 
Antropometri Penentuan Status Gizi Anak

Kompas. 2015. 1.918 Anak Menderita Gizi Buruk di NTT. Diakses dari http://print.kompas.com/baca/regional/ nusantara/2015/06/23/1-918-AnakMenderita-Gizi-Burukdi-NTT tanggal 29 Januari 2016

Kristiani, 2006. Pemanfaatan Pelayanan Posyandu Di Kota Denpasar. http://lrckmpk.ugm.ac.id

Moehji, Sjahmein.2003. Ilmu Gizi Penanggulangan Gizi Buruk. Papas Sinar Sinanti. Jakarta.

Muaris, Hindah. 2006, Lauk Bergizi Untuk anak balita, PT Gramedia Pustaka Utama: Jakarta

M. Dachlan. Y. Al-Barry, Yustina Akmalia, S.Kep, A. Rahman Usman. 2009. Kamus Istiah Medis. Yogyakarta

Nelson. 1996. Ilmu Kesehatan Anak. Ed 15. Vol 1. Terjemahan A. Samil Wahab. 1999. EGC. Jakarta.

Nursalam. 2007. Konsep dan Penerapan Metodologi Penelitian Ilmu Keperawatan : Pedoman Skripsi, Tesis dan Instrumen Penelitian Keperawatan Edisi Ketiga. Salemba Medika : Jakarta.

Notoatmodjo, Soekidjo. (2003). Ilmu Kesehatan Masyarakat (PrinsipPrinsip Dasar). Rineka Cipta. Jakarta.

Notoadmodjo, S. 2011. Kesehatan Masyarakat. Jakarta: Rineka Cipta

Notoatmodjo, Soekidjo. 2005. Promosi Kesehatan Teori dan Aplikasi. Rineka Cipta : Jakarta.

Pujiadi, Solihin. Ilmu Gizi Klinis Pada Anak. Edisi III. FK-UI. 1997.

Ranuh ddk. (2008). Pedoman Imnunisasi di Indonesia. Jakarta: Satgas ImunisasiIDAI

Ridha, 2008. Masalah Rendahnya Penimbangan Balita Di Posyandu Dan Pemecahannya Menurut Mutu Pelayanan Kebidanan. http://one.indoskripsi.com

Rusilanti. 2008. Menu Sehat untuk Balita. Jakarta: Kawan Pustaka

Salham, 2007. Analisis Keberadaan Kader Pos Pelayanan Terpadu Posyandu
Terhadap Revitalisasi Posyandu Di Sulawesi Tengah http://dinkesprovsulteng.wordpress.co $\mathrm{m}$

Setiati, E. 2009, Mengenal Penyakit Balita Dilengkapi dengan Pencegahannya. Yogyakarta: Medika

Santoso, Soegeng. 1999. Kesehatan dan Gizi. Rineka Cipta . Jakarta.

Soetjiningsih. 1995. Tumbuh Kembang Anak. EGC. Jakarta.

Supariasa, I. D. N., Bakri, B., dan Fajar, I. 2012. Penilaian Status Gizi. Jakarta

Sulistiyani. 2010. Gizi masyarakat 1 (masalah gizi utama di Indonesia). Jember: Jember University Press

Supartini, Y. 2010. Buku Ajar Konsep Dasar Keperawatan Anak. Jakarta: EGC. 2000. Makanan Pendamping ASI. Depkes RI. Jakarta

Suhardjo. 2007 . Sosial Budaya Gizi. Bogor: Pusat Antar Universitas Pangan dan Gizi. IPB.

Supartini Y. 2010. Buku Ajar Konsep Dasar Keperawatan Anak. Jakarta: EGC

Syakira. 2009. Tentang Posyandu. http://syakira-blog.blogspot.com. Diakses 8 Mater 2017 